ANUVA Volume 1 (2): 79-91, 2017

Copyright C2017, ISSN: 2598-3040 online

Available Online at: http://ejournal.undip.ac.id/index.php/anuva

\title{
Gaya Rayuan Lelaki dalam Puisi "To His Coy Mistress" Karya Andrew Marvell Berdasarkan Kajian Stilistika
}

\author{
Jumino $^{1 *)}$ \\ ${ }^{1}$ Program Studi S-1 Sastra Inggris, Fakultas Ilmu Budaya, Universitas Diponegoro, \\ Jl. Prof. Soedarto, SH, Tembalang, Semarang. \\ ${ }^{*}$ Korespondensi: juminoya@gmail.com
}

\begin{abstract}
The poem "To His Coy Mistress" written by Andrew Marvel is a hedonistic poem. This poem describes a man trying to seduce a beautiful and honour woman to make love with him. By applying various language styles, the man seduces the woman as an honour and perfectly beautiful lady. However, this condition will be useless unless she can make use of it. So, the man tries to seduce the woman by mentioning her three conditions: what happened in the past, happening at present, and what will in the future in order that the she will not regret. The way the man seduces is very bombastic but also conditionally logical one. Firstly, he adores the woman; then, he shows the reality of life to make her accept his desire of making love with her.
\end{abstract}

Keywords: love, desire, seduction, adoration

\begin{abstract}
Abstrak
Puisi "Untuk Nyonya Coy Nyonya" yang ditulis oleh Andrew Marvel adalah puisi hedonistik. Puisi ini menggambarkan seorang pria mencoba merayu seorang wanita cantik dan terhormat untuk bercinta dengannya. Dengan menerapkan berbagai gaya bahasa, pria tersebut menggoda wanita tersebut sebagai kehormatan dan wanita yang sangat cantik. Namun, kondisi ini akan sia-sia kecuali jika dia bisa memanfaatkannya. Jadi, pria tersebut mencoba merayu wanita tersebut dengan menyebutkan tiga kondisi: apa yang terjadi di masa lalu, terjadi saat ini, dan apa yang akan terjadi di masa depan agar dia tidak menyesalinya. Cara pria menggoda itu sangat bombastis tapi juga logis secara kondisional. Pertama, dia memuja wanita itu; Kemudian, ia menunjukkan realitas kehidupan untuk membuatnya menerima keinginan bercinta dengannya.
\end{abstract}

Kata kunci: cinta, hasrat, rayuan, pujaan

\section{Latar Belakang Masalah}

Secara umum karya sastra ditujukan untuk menghibur sekaligus memberi pelajaran yang berguna bagi para penikmatnya. Tidak seperti jenis karya sastra yang lain, karya sastra puisi lebih menekankan faktor emosi dari pada faktor rasio dalam mengepresikannya. Untuk itu para penyair mengunakan diksi, imaji, gaya bahasa, irama, dan persajakan dalam memperkuat nilai kepuitisan tersebut dari karya-karya mereka.

Menyadari betapa penting unsur-unsur tersebut di atas, dalam artikel ini dibahas penggunaan stilistika gaya bahasa untuk memahami makna puisi "To His Coy Mistress" karya Andrew Marvell dengan judul “Gaya Rayuan Lelaki dalam Puisi 'To His Coy Mistress' Karya Andrew Marvell Berdasarkan Kajian Stilistika". Selanjutnya penulis membatasi kajian pada stilistika gaya bahasa yang digunakan Andrew Marvell dalam puisi tersebut. Penulis menilai unsur tersebut memberikan peran yang penting dalam menyampaikan suatu makna puisi. 


\section{Tinjauan Teoritis}

\subsection{Stilistika Gaya Bahasa}

Stilistika (stylistics) merupakan ilmu mengenai gaya bahasa, bagaimana sesuatu diungkapkan dengan cara tertentu, sehingga tujuan yang dimaksudkan bisa dicapai secara maksimal. Dalam hubungan ini berupa istilah majas. Majas diterjemahkan dari kata trope (Latin), figure of speech (Inggris), berarti persamaan atau kiasan. Jenis majas sangat banyak, seperti: hiperbola, paradoks, sarkasme, inversi, dan sebagainya. Namun demikian, pada umumnya majas dibedakan menjadi empat kelompok, yaitu: majas penegasan, perbandingan, pertentangan, dan majas sindiran. Majas inilah yang paling banyak dikenal, baik dalam masyarakat pada umumnya maupun dalam bidang pendidikan (Ratna, 2008: 3).

Menurut Klarer (2004: 77), stilistika memfokuskan bahasan pada struktur gaya bahasa, elemen akustik dan gaya bahasa retorikal dalam bahasan teks. Adapun menurut Wales (2001: 373), stilistika sebagai lahan bahasan yang diadopsi dari kritik sastra dan sejarah karya seni, bertujuan tidak hanya untuk mendeskripsikan ciri-ciri formal sebuah teks. Ratna (2008: 232-233) juga menyebutkan bahwa gaya (bahasa) merupakan keseluruhan cara pemakaian bahasa oleh pengarang. Selanjutnya, stilistika merupakan ilmu atau teori yang berkaitan dengan pembicaraan mengenai gaya bahasa.

Harsono (1999: 51) mempertegas bahwa stilistika meneliti fungsi puitik bahasa, dengan salah satu langkah penelitian ialah melakukan bahasan terhadap aspek bahasa figuratif.

\subsubsection{Definisi Gaya Bahasa}

Terdapat banyak definisi mengenai gaya bahasa. Pertama, menurut Perrine, gaya bahasa (figure of speech) ialah "a way of saying one thing and meaning another". Gaya bahasa merupakan cara menyatakan terhadap sesuatu namun dengan maksud yang berbeda, Kedua, menurut Keraf (2000: 113), gaya bahasa merupakan cara mengungkapkan pikiran melalui bahasa secara khas yang memperlihatkan jiwa dan kepribadian penulis (pemakai bahasa). Ketiga, menurut Holman (1985: 185), gaya bahasa (figure of speech) sebagai "the various uses of language which depart from customary construction, order, or significance in order to achieve special effects or meaning". Dengan kata lain, gaya bahasa merupakan keberagaman penggunaan bahasa yang terpisah dari konstruksi, susunan, atau arti lugas dengan maksud untuk mencapai pengaruh atau makna khusus. Keempat, menurut Ratna (2008: 164-165), majas (figure of speech) merupakan pilihan kata tertentu sesuai dengan maksud penulis (penyair) atau pembicara (ahli pidato) dalam rangka memperoleh aspek keindahan.

Berdasarkan keempat pendapat di atas, bisa disimpulkan bahwa gaya bahasa merupakan cara penggunaan bahasa untuk menyampaikan arti yang lebih dalam dan mengena namun terasa lebih indah dibandingkan dengan penggunaan bahasa secara lugas. Juga penggunaan gaya bahasa bisa menimbulkan efek-efek tertentu dalam diri emosi pembaca, seperti rasa marah, benci, kagum, kasihan, dan sebagainya. 


\subsubsection{Jenis-jenis Gaya Bahasa}

Menurut Holman, gaya bahasa (figure of speech) secara umum dikelompokkan menjadi dua jenis, yakni gaya bahasa retoris dan gaya bahasa kiasan atau majas. Gaya bahasa retoris (rhetorical figures of speech) merupakan gaya bahasa (figure of speech) dengan menggunakan perpindahan dari penggunaanpenggunaan bahasa standar sehari-hari untuk mendapatkan efek khusus tanpa mengubah makna dasar dari kata-kata yang digunakan.

"Figures of speech are of two major kinds: rhetorical figures, which are departures from customary or standard uses of language to achieve special effects without a change in the radical meaning of the words; and tropes, in which basic changes in the meaning of words occur." (1985: 185)

Selanjutnya menurut Keraf (2000: 129), gaya bahasa retoris semata-mata merupakan penyimpangan dari konstruksi biasa untuk mencapai efek tertentu. Beberapa jenis gaya bahasa retoris berupa aliterasi, asonansi, dan sebagainya. Adapun gaya bahasa majas/kiasan (figurative Language) merupakan perpindahan penggunaan-penggunaan arti, kontruksi, susunan kata untuk memperoleh kesegaran dan kekuatan ekspresi, menciptakan efek imaji, mendiskripsikan melalui analogi, menemukan atau mendapatkan kesamaan atau sebaliknya. Jenis-jenis bahasa kiasan ini ialah antithesis, apostrophe, climax, hyperbole, irony, metaphor, metonymy, personification, simile, synecdoch, dan paradox.

Selanjutnya Perrine (1969: 71) menyebutkan bahwa bahasa majas memiliki beberapa fungsi berikut:

First, figurative language affords us imaginative pleasure. Second, figures of speech are a way of bringing additional imagery into verse, of making the abstract concrete, of making poetry more sensuous. Third, figures of speech are a way of adding emotional intensity to otherwise merely informative statements and of conveying attitudes along with intbrmation. Fourth, figures of speech are a means of concetration, a way of saying much in brief compass.

Dari pernyatan tersebut bisa difahami bahwa empat fungsi bahasa majas tersebut ialah: pertama, bahasa majas mampu menciptakan kenikmatan imajinatif bagi penikmat; kedua, bahasa majas membawa dan menambahkan gambaran-gambaran angan ke dalam puisi sehingga gambaran dikehendaki menjadi lebih konkrit dan bisa ditangkap panca indra; ketiga, bahasa majas menambah intensitas emosional; dan keempat, bahasa majas bisa mengungkap banyak hal datam bentuk yang ringkas dan padat.

Secara umum bisa disebutkan bahwa bahasa majas menjadi unsur penting dalam puisi karena bisa memberikan nilai puitis, bisa merangsang emosi, dan menyampaikan makna mendalam yang bersifat subjektif. Selanjutnya bahasa majas mampu membandingkan atau mengumpamakan sesuatu dengan cara yang lain. Sebagaimana dinyatakan Pradopo (1987: 62), bahwa bahasa majas mengiaskan atau mempersamakan sesuatu hal dengan hal lain untuk memperjelas suatu gambaran lebih menarikdan hidup. Selanjutnya jenis jenis gaya bahasa yang akan digunakan dalam membahas puisi "To His Coy Mistress" ialah metafora, simile, hiperbola, dan alusio. 


\subsubsection{Metafora}

The New International Webster's Comprehensive Dictionary of the English Language (2003: 800) menyebutkan bahwa "metaphor is a figure of speech in which one object is likened to another by speaking of it as if it were that other: distinguished from simile by not employing any word of comparison, such as 'like' or 'as". Selanjutnya, Perrine (1987: 565). menyebutkan bahwa "metaphor is used as a means of comparing things that are essentially unlike. In metaphor the comparison is implied that is, the figurative term is substituted/or identified with the literal term. Matafora digunakan sebagai sarana untuk membandingkan benda-benda yang pada dasarnya masing-masing mempunyai arti harfiah yang berbeda.

Menurut Abrams "metaphor is a way of speaking or writing in which one thing is said to be another thing” (1971: 78). Metafora merupakan cara pengungkapan atau penulisan dengan membandingkan satu benda dengan benda lain.

Contoh metafora misalnya pada saat Tennyson dalam puisinya yang berjudul "Eagle" mengatakan claps the crag with crooked hands. Dalam puisi tersebut ia juga menggunakan metafora karena ia mengganti kata claws (cakar) dengan crooked hands atau tangan-tangan yang melengkung (Perrine, 1969: $65)$.

Berdasarkan dua kutipan di atas, bisa disimpulkan bahwa metafora merupakan gaya bahasa kiasan yang memperbandingkan sebuah objek dengan objek lainnya secara langsung, tanpa menggunakan kata pembanding seperti as, similar to, like, resemble. Metafora bisa dikatakan semacam analogi yang membandingkan dua hal secara langsung, yaitu bila suatu objek mempunyai sifat, perilaku atau aspek tertentu maka diterapkan langsung pada suatu objek yang diperbandingkan.

\subsubsection{Simile}

Simile merupakan bahasa majas yang membandingkan dua hal yang pada dasarnya tidak sama dengan melibatkan kata-kata pembanding misalnya, "seperti”, "bak", "bagaikan”, "laksana", dan lain sebagainya. Dengan kata lain, perbandingan dalam simile dinyatakan secara tersurat. Keraf (2000: 138) mendefinisikan simile atau persamaan sebagai perbandingan yang bersifat eksplisit, yaitu langsung menyatakan sesuatu sama dengan hal yang lain.

Birkerts (1993: 583) menyebutkan "simile expresses the fact of likeness with a co"mparative link such as like or as". Simile mengekspresikan realita mengenai kemiripan antara dua hal dengan memakai kata hubung "seperti" atau "bagaikan".

Contoh penggunaan simile terdapat dalam penggalan puisi "The Eagle" karya Lord Arfred Tennyson, pada larik keenam, "And like a thunderbolt he falls" (Perrine 1988: 411). 


\subsubsection{Hiperbol}

Minor dan Rausch (1998: 102) menyebutkan hiperbol sebagai "Obvious, extravagant exaggeration or overstatement, not intended to be taken literally, but used figuratively to create humor or emphasis". Hiperbol merupakan gaya bahasa yang menyebutkan sesuatu secara berlebih-lebihan dengan tujuan untuk menekan sesuatu atau juga bisa untuk memperolok-olok terhadap suatu hal atau keadaan. Contoh hiperbol hiperbol terdapat dalam puisi Andrew Marvell's "To His Coy Mistress," My vegetable love should grow Vaster than empires, and more slow, An hundred years should go to praise thine eyes, and on thy forehead gaze: Two undred to adore each breast: But thirty thousand to the rest.

\subsubsection{Alusio}

Alusio merupakan gaya bahasa sindiran yang mengacu pada peristiwa penting dalam mitologi atau sejarah zaman dahulu. Salah satu contoh ialah kata "Yoshua" yang digunakan Lord Chesterfield pada saat menyampaikan sindiran saat jamuan makan, "Your excellencies have taken from me," he said, "all the greatest luminaries of heaven, and the stars are too small for me to make a comparison of my royal master; I therefore beg leave to give your excellencies-Joshua!” (Perrine, 1988: 623).

Untuk pembaca akrab dengan Alkitab - bagi orang yang mengakui cerita Alkitab - sindiran Lord Chesterfield datang sebagai hal yang menakjubkan dari suatu kecerdasan. Satu kata "Joshua," dalam pikiran pembaca mengarah pada kisah dalam Alkitab bagaimana kapten Israel menghentikan matahari dan bulan bisa menyelesaikan pertempuran dan menaklukkan musuh sebelum malam tiba.

\subsubsection{Simbol}

Secara umum simbol bisa didefinisikan sebagai sesuatu yang berarti lebih dari arti apa adanya. "The Road Not Taken", misalnya, menyangkut pilihan yang dibuat antara dua jalan oleh orang keluar berjalan di hutan. Bisa ditafsirkan bahwa pilihan jalan merupakan simbol untuk setiap pilihan dalam hidup antara berbagai pilihan yang muncul hampir sama menarik tetapi akan menghasilkan perbedaan besar dari setiap jalan yang akan dilalui. "The Road Not Taken', for instance, concerns a choice made between two roads by a person out walking in the woods" (Perrine, 1988: 585).

Sebagaiana pendapat Perrine, Meyer menyebutkan bahwa simbol mempunyai makna lebih dalam dari makna kata harfiahnya. "A symbol is something that represents something else. An object, person, place, event, or action can suggest more than its literal meaning (1995: 581). Sebagai contoh kata crown yang berarti hiasan kepala bisa menjadi simbol kekuasaan, tahta, atau kerajaan. Reaske manambahkan bahwa, "An image, through repeated use in the same way (sense) becomes a symbol." (Reaske, 1970: 42). Hal ini berarti bahwa citra yang berulang-ulang muncul bisa jadi merupakan simbol. 


\subsection{Tema Puisi}

Tema merupakan ide atau gagasan sentral yang dikembangkan dalam puisi. Konsep utama itu dikembangkan dalam puisi. Tema menjadi ide dasar yang disampaikan seorang penyair. "Theme is the central concept developed in poem. It is the basic idea which the poet is trying to convey....." (Reaske, 1966: 42).

Selanjutnya Perrine (1969: 149) menyebutkan bahwa "The idea in a poem is part of the total experience it communicates." Gagasan-gagasan dalam puisi merupakan bagian dari pengalaman menyeluruh yang ingin disampaikan seorang penyair, Oleh karena itu, para penikmat puisi diharapkan bisa memahami hal-hal tersebut, sehingga mereka bisa menangkap tema yang terkandung dalam puisi sebagai sarana memperkaya pemahaman hidup mereka.

\section{Pembahasan Puisi}

Berikut ini merupakan puisi "To His Coy Mistress" karya Andrew Marvell.

\section{To His Coy Mistress}

Karya Andrew Marvell

Had we but world enough, and time,

This coyness, lady, were no crime.

We would sit down and think which way

To walk, and pass our long love's day.

Thou by the Indian Ganges' side

Shoudst rubies find; I by the tide

Of Humber would complain. I would

Love you ten years before the flood,

And you should, if you please, refuse

Till the conversion of the Jews.

My vegetable love should grow

Vaster than empires and more slow;

An hundred years should go to praise

Thine eyes, and on thy forehead gaze;

Two hundred to adore each breast,

But thirty thousand to the rest;

An age at least to every part,

And the last age should show your heart.

For, Lady, you deserve this state,

Nor would I love at lower rate.

But at my back I always hear

Time's winged chariot hurrying near;

And yonder all before us lie

Deserts of vast eternity.

Thy beauty shall no more be found;

Nor, in thy marble vault, shall sound

My echoing song; then worms shall try 
That long-preserved virginity,

And your quaint honor turn to dust,

And into ashes all my lust:

The grave's a fine and private place,

But none, I think, do there embrace.

Now therefore, while the youthful hue

Sits on thy skin like morning glow,

And while thy willing soul transpires

At every pore with instant fires,

Now let us sport us while we may,

And now, like amorous birds of prey,

Rather at once our time devour

Than languish in his slow-chapped power.

Let us roll all our strength and all

Our sweetness up into one ball,

And tear our pleasures with rough strife

Thorough the iron gates of life:

Thus, though we cannot make our sun

Stand still, yet we will make him run.

(Perrine, 1988: 380-381)

\subsection{Bahasan Metafora}

Dalam puisi "To His Coy Mistress" ini, tokoh I ialah lelaki. Si tokoh I menyampaikan pemyataan hasrat nafsu cintanya dalam puisi tersebut kepada seorang wanita (his mistress).

\subsubsection{Bahasan "To His Coy Mistress" Bait Pertama}

Bait pertama puisi "To His Coy Mistress" terdiri atas larik pertama sampai larik ke-20. Secara garis besar, bait ini merupakan bentuk pengandaian yang hiperbolis, berisi rayuan cinta secara berlebih-lebihan dari seorang lelaki terhadap seorang wanita.

Pada larik pertama, si tokoh $I$ memulai pemyataan cinta dengan sebuah pengandaian tipe tiga yang tidak mungkin terjadi: had we. Si tokoh I mengutarakan kepada wanita bahwa jika mereka mempunyai cukup ruang dan waktu (had world enough and time) untuk terus bersama, maka si tokoh I akan melakukan banyak hal terhadap si wanita dalam keabadian waktu tersebut. Namun pada kenyataannya, mereka tidak memiliki hal tersebut.

Metafora pada larik pertama dimulai dengan bentuk pengandaian (conditional) Had we yang merupakan penukaran susunan baku If we had, karena membutuhkan penekanan yang kuat pada awal puisi ini. Had we yang disampaikan oleh si tokoh $I$, menyebutkan realita yang berkebalikan. World enough mengacu pada ruang atau tempat manusia berada di dunia selama masih hidup. Ketika time mengacu pada umur atau usia manusia hidup di dunia. Had we but world enough, and time, merupakan metafora ketakutan si tokoh I terhadap kehancuran atau kebinasaan, karena sebuah kesadaran bahwa keberadaan manusia di dunia dibatasi oleh dimensi ruang dan waktu. Namun demikian si tokoh $I$ 
menyampaikan bentuk pengandaian yang berlebih-lebihan yang berkebalikan dengan realita.

Pada larik kedua, sikap malu-malu (coyness)yang dari si wanita dikatakan oleh si tokoh $I$ bukan sebagai sebuah kejahatan (crime). Crime dalam hal ini merupakan sikap yang tidak menyenangkan atau memuaskan bagi pasangan lainnya. Dalam hal ini ialah si tokoh $I$. Si tokoh $I$ menyatakan bahwa jika mereka memiliki ruang yang tidak terbatas dan waktu yang tidak berkesudahan maka sikap si wanita yang menunggu dan malu-malu bukan sebuah kejahatan. Akan tetapi, dalam kenyataannya yang terjadi ialah sebaliknya. Maka bisa dikatakan bahwa pemyataan ini merupakan ironi terhadap sikap keengganan si wanita dalam menanggapi rayuan si tokoh $I$.

Kata think which way ... To walk merupakan metafora yang mengacu pada jarak antara Sungai Gangga (Ganges) pada larik ke-5 dan sungai Humber pada larik ke-7. Sungai Gangga merupakan sungai suci yang mengalir di India dan menjadi pusat berkembangnya peradaban masyarakat India. Ketika sungai Humber adalah sungai di kota Hull, pada saat Marvell menghabiskan masa kecilnya di kota ini dan kembali lagi ke kota Hull setelah menjadi anggota parlemen. Si tokoh I mengatakan bahwa jika keduanya terpisah - si wanita di tepi sungai Gangga untuk menemukan batu-batu rubi (rubies), ketika dirinya bersama pasang-surut sungai Humber. Rubies pada larik ke-6 bermakna batu rubi yang simbol jimat untuk melindungi, memelihara dan mempertahankan keperawanan si wanita.

Frasa long love's day pada larik ke-4 yang bisa dimaknai sebagai spesifik jangka waktu yang dihabiskan si tokoh $I$ untuk bersama dengan si wanita. Atau jika dikaitkan dengan larik ke-13 sampai 20, makna frasa di atas bisa berupa masa waktu yang panjang untuk memuja bagian tubuh wanita pujaan hatinya, yaitu hingga ribuan tahun.

Kata long tidak hanya mengacu pada waktu, tetapi juga berarti jarak. Jarak yang dimaksud terdapat dalam larik selanjutnya, yakni gambaran Indian Ganges - aliran sungai mengindikasikan waktu yang terus mengalir seperti air, lebih khusus lagi dalam khayalan keabadian versi si tokoh $I$ bahwa waktu tidak akan berhenti mengalir. Humber menyiratkan perjalanan waktu yang panjang kisah cinta tersebut akan naik-turun sebagaimana pasang surutnya air sungai Humber tersebut.

Selanjutnya si tokoh $I$ melanjutkan rayuannya dengan pemyataan bahwa cintanya akan tumbuh lebih luas dari pada kekuasaan sebuah kekaisaran: My vegetable love should grow; Vaster than empires and more slow. Frasa vegetable love yang merupakan sebuah metafora. yang mengandung makna tersirat bahwa cinta si tokoh $I$ bukanlah cinta biasa, namun penuh keagungan. Seperti tanaman pada umumnya, vegetable love memiliki potensi untuk tumbuh subur dan menjadi sumber utama dalam siklus kehidupan makhluk di bumi. Tanaman menjadi kunci kehidupan bagi makhluk hidup, begitu pula maksud yang ingin disampaikan oleh si tokoh $I$, bahwa hasrat cinta terhadap wanita pujaannya akan tumbuh begitu luas dan berlangsung selamanya. Meskipun membutuhkan waktu perlahan namun pasti bagi pertumbuhan sebuah tanaman, si tokoh $I$ menegaskan bahwa tanaman cintanya akan tumbuh lebih luas dibandingkan waktu sebuah kerajaan dengan wilayah kekuasaannya. 
Kata state, pada For Lady, you deserve this state, tidak hanya menunjukkan makna leksikal keadaan, namun lebih pada makna mengagungkan. Si tokoh $I$ berusaha memenangkan hati wanita yang dicintainya dan memujinya dengan kata-kata yang lembut sikap penuh rayuan dan sanjungan untuk menarik perhatian si wanita. Konotasi ini digunakan untuk menyangatkan arti keadaan si wanita yang terhormat. Si tokoh I menyampaikan bahwa ia akan menghabiskan seluruh waktu hidupnya demi melihat keindahan si wanita, yakni melewatkan 100 tahun untuk memandang wajahnya dan memuji kecantikannya, 200 tahun untuk mengagumi payudaranya, dan 30.000 tahun sisanya untuk menikmati keindahan bagian tubuh yang lain. Pemyatan ini tersebut menyiratkan bahwa si tokoh $I$ mencari keindahan seksualitas wanita tersebut.

\subsubsection{Bahasan "To His Coy Mistress" Bait Kedua}

Bait kedua puisi ini ialah larik ke-21 sampai larik ke-32. Bait ini lebih menceritakan realita atau masalahmasalah yang dihadapi oleh si tokoh $I$. Pada bait kedua, nada penyampaian si tokoh $I$ berubah menjadi serius dan mengacu pada realita.

Pada larik ke-21, kata sambung but menunjukkan kebalikan realita terhadap khayalan si tokoh $I$. Khayalan mengenai bagaimana hal-hal mungkin terjadi jika dua orang pasangan yang bercinta-kasih memiliki semua waktu di dunia, terbantahkan dengan penekanan realita bahwa mereka tidak punya cukup waktu. Pernyataan tersebut dilanjutkan dengan frasa at my back, yakni konotasi terhadap perkataan orangorang terdahulu yang memberikan petuah mengenai hakikat waktu dan kehidupan yang didengar oleh si tokoh $I$.

Terdapat gambaran jelas mengenai kehidupan dalam metafora time's winged chariot pada larik ke-22 yang bisa dimaknai sebagai the flying chariot of time, metafora kenikmatan fantasi terbang dalam menikmati hubungan seksual. Hubungan seksual menjadi sarana menikmati kehidupan, disamping bertempur melawan waktu yang terus berjalan dan kematian yang semakin mendekat. Kemudian beberapa larik selanjutnya akan memberikan argumen bahwa kecantikan si wanita akan sia-sia apabila tidak dimanfaatkan pada saat masih hidup di dunia, sehingga pada akhimya si si tokoh $I$ mengajak si wanita untuk menikmatinya.

Pada larik ke-26, marble vault merupakan metafora yang menyiratkan penyampaian makna kelamin wanita (vagina). Dari semua khayalan yang disampaikan dengan gairah yang menyala-nyala, pada akhimya berujung pada keinginan si tokoh I untuk mendapatkan keperawanan si wanita. Meski dengan cara apapun si wanita mempertahankan keperawanannya tersebut, tetap pada akhimya semua cinta harus berakhir menjadi abu.

Frasa Echoing song pada larik ke-27 berupa metafora tentang kesedihan hati si tokoh $I$ yang tidak dipedulikan oleh sikap malu-malu dan keengganan si wanita. Si tokoh I menekankan bahwa jika permintaannya ditolak maka mang privasi milik wanita tersebut akan menggemakan lagu kesedihan 
hatinya. Metafora ini selain untuk merebut hati, berupa isyarat keadaan yang lebih baik dipilih oleh wanita tersebut. Menurut si tokoh $I$, jauh lebih baik menerima permintaannya untuk menerima ajakan bercinta dari pada membiarkan keperawanannya digerogoti oleh cacing tanah kuburan di kemudian.

Selanju tnya pada larik ke-28, worms atau cacing tanah yang telah disebut-sebut di atas pada dasarnya menjadi pembanding pilihan yang ditawarkan terhadap si wanita. Tetap mempertahankan keperawanannya dari si tokoh $I$, atau mau tidak mau suatu saat kematian yang merenggutnya akan mengantarkan dirinya pada cacing tanah yang siap menghancurkan tubuhnya.

Kedua pilihan tersebut pada dasarnya menegaskan maksud si tokoh $I$ terhadap si wanita bahwa ia tidak punya pilihan yang lebih baik selain disampaikan dengan gairah yang menyala-nyala, pada akhimya berujung pada keinginan si tokoh I untuk mendapatkan keperawanan si wanita. Meski dengan cara apapun si wanita mempertahankan keperawanannya tersebut, tetap pada akhimya semua cinta harus berakhir menjadi abu dan kesucian harus berakhir menjadi debu. Jika bukan si tokoh I yang mendapatkan keperawanan tersebut, cacing tanah nantinya yang akan menikmatinya pada saat si wanita sudah masuk liang lahat.

Kata Grave pada larik ke-31 menjadi spesifikasi keterbatasan ruang yang akan dihuni oleh manusia dalam ancaman ketidakabadian waktu. Makam kecil menjadi metafora tentang pengandaian ruang yang tidak terbatas, world enough, pada larik pertama. Segala bentuk pengandaian di bait pertama berujung pada titik kematian. Makam berupa simbol kesendirian yang hanya diselimuti oleh tanah. Selanjutnya menurut si tokoh $I$, setelah berada di dalam makam, tidak ada lagi kekasih atau lawan jenisnya yang may mendekat sebagaimana pada saat berada di dunia, sebagaimana pada larik ke-32, But none, I think, do there embrace.

\subsubsection{Bahasan “To His Coy Mistress”' Bait Ketiga}

Bait ketiga dari puisi ini terdiri dari larik ke-33 sampai dengan larik ke-46. Bait ini merupakan pemyataan akhir alasan-alasan yang telah dikemukakan pada dua bait sebelumnya. Pengarang menawarkan sebuah pemyataan sebagai ajakan logis dari ide-ide yang telah digambarkan dalam bait pertama dan kedua. Pada bait terakhir ini, si tokoh $I$ mengurangi ironi kasamya dengan mengajak si wanita untuk menikmati waktu dengan bercinta.

Pertama, dalam bait ketiga ini frasa Now, therefore (larik -33) dan Now let us (larik ke-37) merupakan metafora penyadaran dan ajakan dari si tokoh $I$ terhadap si wanita pujaannya untuk bermain cinta selagi mereka dalam keadaan semangat muda penuh gairah. Bergerak dari formalitas pemujian keindahan wanita pada bait pertama dan penyadaran realita pada bait kedua, si tokoh $I$ menaapakkan nafsu yang seungguhnya, yaitu nafsu birahinya yang menggebu-gebu dengan menekankan ancaman akan waktu yang terus berlalu. Hal hal tersebut diindikasikan dengan kata-kata instant, at once, dan languish in slow-chapped power. 
Willing soul pada larik ke-35 menyiratkan jiwa bergairah yang mendasari sikap si tokoh I terhadap si wanita. la bersungguh-sungguh memohon wanita, bahkan cenderung memaksa, untuk memberikan respon lebih cepat dan partisipasi lebih aktif bercinta. Gejolak gairah Nafsu si tokoh I menuntut si wanita untuk tidak perlu malu-malu, segan-segan, apalagi enggan.

Frasa Instant fires pada larik ke-36 menyiratkan lebih lanjut mengenai gairah si tokoh $I$. Gairah tersebut diibaratkan seperti bara api yang membakar secara tiba-tiba, dan gelora tersebut juga terus berlangsung. Oleh karena itu, si tokoh I mengajak si wanita untuk melakukannya selagi mereka bisa sebagaimana disampaikan pada larik ke-37, Now let us sport us while we may.

Frasa Sport us pada larik di atas bukan bermakna harfiah berolahraga, akan tetapi lebih pada arti berusaha lebih keras menggenapkan seluruh potensi yang dimiliki selagi masih ada kesempatan. Kondisi ini akan dipertegas dengan metafora yang terdapat pada larik ke-41 berikutnya, Amorous birds of prey merupakan yang merupakan metafora penggambaran sifat dan hakikat waktu. Menurut si tokoh $I$, waktu yang digunakan dengan baik dan dioptimalkan pemanfaatannya memberikan keuntungan atau kebaikan. Sebaliknya, jika si pengguna waktu tidak bisa memanfaatkan dengan baik, waktu akan melahap atau mengganyang si pengguna waktu tersebut layaknya burung pemangsa.

Selanjtnya frasa Roll all our strength (larik ke-41) bermakna mengerahkan segenap energi dan potensi untuk bisa menikmati kehidupan dunia. Hal ini disusul dengan metafora selanjutnya. one ball (larik ke-42), yang menyiratkan akan segala kekuatan yang telah disebutkan sebelumnya untuk disatukan dalam satu kesatuan dan penyatuan hsrat bercinta yang utuh dan berimbang. Hal ini tersambung dengan frasa Tear our pleasure di larik ke-43 yang berarti memperjuangkan kesenangan-kesenangan meskipun harus bersusah-payah menaklukkan halangan dan rintangan yang ada. Hal ini diibaratkan dengan Iron gates of life pada larik.

Puisi "To His Coy Mistress" diakhiri dengan dua larik yang mengacu pada pada alusio yang mengisahkan tentang mitologi klasik Yunani, Thus, though we cannot make our sun (larik ke-45) berlanjut ke Stand still, yet we will make him run. (larik ke-46). Guerin et al. (1992: 32) menyatakan bahwa alusio tersebut mengacu pada mitologi Joshua yang menghentikan matahari, sehingga bangsa Israel bisa memenangkan dalam pertempuran melawan musuh mereka. Hal ini juga dikaitkan degan mitos Zeus yang menghentikan matahari. Zeus memerintah sang matahari tetap berada di tempatnya agar ia bisa lebih belama-lama menikmati malam panjang bermain cinta bersama Alemenam, kekasih pujaan hati. Dalam puisi ini, melalui si tokoh $I$, ingin menekankan bahwa manusia yang tidak memiliki kekuatan selayaknya Joshua atau Zeus yang bisat menghentikan waktu. Oleh karena itu, alangkah sia-sianya kalau manusia hanya melewati waktu begitu saja tanpa bisa menikmatinya.

\section{Gaya Rayuan Lelaki dalam Puisi "To His Coy Mistress"}

Berdasarkan bahasan stilistika gaya bahasa terhadap puisi Andrew Marvell, "To His Coy Mistress" bisa 
diambil tema dasar bahwa hidup yang tidak abadi ini harus dinikmati sepuasnya, terutama dalam hal melampiaskan hasrat dan gairah seks dengan lain jenis.

Dalam puisi "To His Coy Mistress" ini, si lelaki atau tokoh $I$ yang sedang jatuh cinta dengan si wanita (mistress) berupaya keras untuk bisa bercinta dengannya. Untuk iti Ia melakukan jurus rayuan untuk menudutkan si wanita. Pertama ia sanjung kecantikan si wanita pujaan hatinya itu dengan berangan-angan setinggi langit. Wanita sempurna yang terhormat tersebut ia sanjung setiap bagian dari tubuhnya yang bisa menimbulkan kegairahan seksual secara berlebih-lebihan agar si wanita merasa sangat tersanjung dan terhormat.

Selanjutnya si lelaki mengarahkan sanjungannya terhadap si wanita beralih pada kenyataan hidup. Manusia hidup tidak kekal. Segala kelebihan fisik seperti kecantikan dan kemolekan tubuh, serta hasrat dan gairah seks akan pudar seiring berlalunya waktu. Manusia kemudian tidak akan berdaya lagi karena menua dan berujung pada kematia.n Setelah itu kebanggaan-kebanggaan yang dumilikinya menjadi tidak berarti sama sekali.

Untuk itu selagi masih hidup manfaatkan kecantikan, kemolekan, nafsu seks guna mengimbangi gairah dan gelora seks darah muda kaum lelaki untuk bercinta. Jangan sampai wanita menyesal di kemudian hari setelah direnggut oleh kematian. Setelah itu, segala hasrat dan keinginan sudah tidak akan pernah bisa dilakukan lagi.

\section{Simpulan}

Dari hasil pembahasan puisi "To His Coy Mistress" karya Andrew Marvell dari tinjauan stilistika bisa ditarik simpulan bahwa hidup ini hanya sebentar dan waktu terus berlalu. Untuk itu selagi masih hidup, alangkah baiknya apabila kesempatan itu tidak disia-siakan begitu saja, terutama dalam hal nafsu bercinta.

\section{Daftar Pustaka}

Birkerts, Sven P. 1993. Literature, the Evolving Canon. Massachusetts: Divison of Simon and Schester, Inc.

Guerin, Wilfred L. dkk. 1992. A Handbook of Critical Approaches to Literature. New York: Oxford University Press, Inc.

Harsono, Siswo. 1999. Metodologi Penelitian Sastra. Semarang: Deaparamartha.

Holman, C.Hugh. 1985. A Handbook to Literature. Indianapolis: ITT Bobbs-Merrill Educational Publishing Company, Inc.

Keraf, Gorys. 2000. Diksi dan Goya Bahasa. Jakarta: PT Gramedia Pustaka Utama.

Klarer, Mario. 2004. An Introduction to Literary Studies. New York: Routledge Taylor \& Francis Group. Morner, Kathleen dan Ralph Rausch. 1998. NTC's Dictionary of Literary Terms. Lincolnwood: NTC 
Publishing Group.

Perrine, Laurence. 1969. Sound and Sense: An Introduction to Poetry (Third Edition). New York: Harcourt Brace Jovanovich, Inc. 1988. Literature Structure, Sound and Sense (Fifth Edition). New York: Harcourt Brace Jovanovich, Inc.

Pradopo, Rachmat Djoko. 1993. Pengkajian Puisi. Gadjah Mada University Press: Yogyakarta

Ratna, Nyoman Kutha. 2007. Estetika Sastra dan Budaya. Yogyakarta: Pustaka Pelajar.

Reaske, Christopher Russel. 1966. How to Analyze Poetry. New York: Monarch Press.

The New International Webster's Comprehensive Dictionary of the English Language. 2003. Columbia: Trident Press International.

Wales, Katie. 2001. A Dictionary ofStylistics Second Edition. England: Pearson Education Limited. 